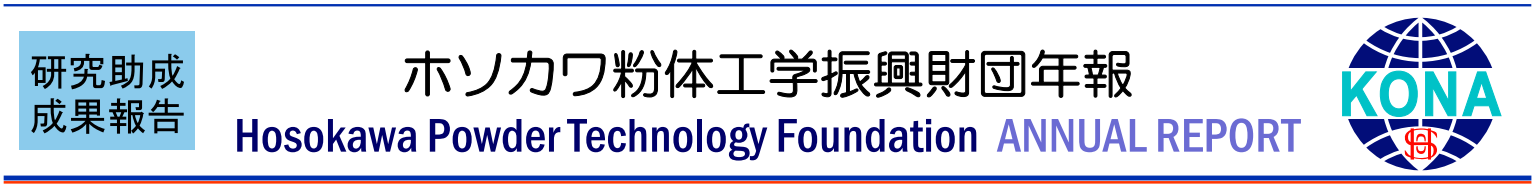

17112

\title{
ナノカーボン表面上での蛋白質コロナの形成機構の解明 \\ Mechanistic Insight into Protein Corona Formation on Nanocarbon Materials
}

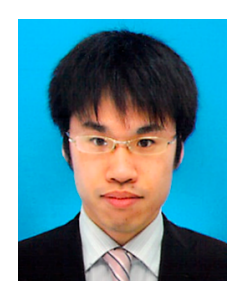

研究代表者 Research leader：平野 篤 Atsushi HIRANO

産業技術総合研究所ナノ材料研究部門 主任研究員

Nanomaterials Research Institute, Advanced Industrial Science and Technology,

Senior Researcher

E-mail: hirano-a@aist.go.jp

\section{抄 録}

カーボンナノチューブ（CNT）などのナノ材料は生体内への取り込み過程の初期段階において蛋白 質によって速やかに覆われることが知られている。このようなナノ材料表面の蛋白質の吸着層は蛋 白質コロナと呼ばれており, ナノ材料の生体内動態や有害性などに影響を与える。しかし, 蛋白質 コロナ形成過程におけるナノ材料と蛋白質の相互作用については現時点では不明な点も多い. 本研 究では, CNT が表面に高密度の蛋白質吸着層を形成し, かつ, 吸着した蛋白質を酸化させる作用 を有することを明らかにした，この酸化機構はナノ材料の生体内動態に関する基礎知見として役立 つと期待される。

\begin{abstract}
Nanomaterials, including carbon nanotubes (CNTs), are coated by proteins in early stages of their uptake into biological systems. The protein layers around the nanomaterial surfaces are called protein corona, which determines the fate pathways and biological impacts of the nanomaterials. However, little is known about interactions of proteins with the nanomaterials during protein corona formation. In this work, we discovered that CNTs form thick and dense protein layers on their surfaces and induce oxidative stress on the proteins. The proposed protein oxidation mechanism will advance the fundamental understanding of the biological safety and toxicity of nanomaterials.
\end{abstract}

研究背景と目的

$$
\text { ナノ材料は生体内に取り込まれると, その表 }
$$
面は速やかに蛋白質によって覆われ，蛋白質コ ロナと呼ばれる層が形成される（Ge C. et al.,
2011）．蛋白質コロナは材料の生体内動態に極 めて大きな影響を与え, 安全性や有害性と深く 関連している，たとえ同一の材料であっても蛋 白質コロナの組成や構造が異なると, 細胞への 取り込み経路が変わることが報告されている 
(Albanese et al., 2014).

本研究では, ナノ材料の安全性の担保や対策 への貢献を目的に，蛋白質コロナの形成機構の 解明を目指した. 研究対象のナノ材料としては, カーボンナノチューブ（CNT）を使用した.

\section{研究方法}

\section{CNT - 蛋白質複合体の酸化還元反応}

CNT 周囲の蛋白質吸着層の緻密性を評価す るために，蛋白質のひとつであるウシ血清アル ブミン（BSA）を吸着させた CNTの水溶液中 での酸化還元反応を赤外光吸収スペクトル測定 によって観察した。酸化還元反応には主として $\mathrm{pH}$ 変化を利用した。一般に，酸性ほど溶存酸 素によるCNT の酸化が進み, $\mathrm{CNT}$ の $\mathrm{E}_{11}$ バン ドに相当する赤外光吸収スペクトル強度の低下 が生じる。なお，本研究で使用したCNTは HiPco 法によって合成されたものである.

\section{CNT と蛋白質の酸化還元反応}

CNT と蛋白質（あるいはアミノ酸）の間に 生じる酸化還元反応を赤外光吸収スペクトル測 定によって観察した。一般に, 蛋白質から CNTに電子が受け渡されることによって, $\mathrm{CNT}$ の $\mathrm{E}_{11}$ バンドに相当する赤外光吸収スペク トル強度の増加が生じる。この強度変化を経時 的に測定することで, 酸化還元反応の進行度を 調べた。 なお，共存する $\mathrm{CNT}$ 試料由来の鉄イ オンの影響を調べるために，鉄イオンの補足剂 (キレート剂) であるエチレンジアミン四酢酸 （EDTA）の添加の効果も調べた.

\section{研 究成果}

\section{CNT-蛋白質複合体の酸化還元反応}

CNT は水溶液中で式 (1) の酸化還元反応を示 す (Zheng, M. and Diner, B.A., 2004).

$$
4\left(\mathrm{e}^{-} \mathrm{h}^{+}\right)_{\mathrm{CNT}}+\mathrm{O}_{2}+4 \mathrm{H}^{+} \leftrightarrow 4\left(\mathrm{~h}^{+}\right)_{\mathrm{CNT}}+2 \mathrm{H}_{2} \mathrm{O}
$$

この反応には溶存酸素とプロトンが関与する ため, 反応の進行度は $\mathrm{pH}$ に大きく影響する。 たとえば, pH が低い酸性ほど CNT は電子 $\left(\mathrm{e}^{-}\right)$ を奪われる。一般に, 表面の電子の受け渡しは 吸着分子の存在によって抑制されるため, 蛋白 質吸着の緻密性を CNT の酸化還元反応の反応 性の変化という視点から定性的に評価した (Nakayama et al., 2018).

図 1 は BSA および界面活性剂のひとつであ るドデシル硫酸ナトリウム（SDS）を吸着させ たCNTの分散溶液（それぞれCNT-BSA と CNT-SDS）の赤外光吸収スペクトルを示して いる，両分散液においても $\mathrm{pH}$ の低下とともに $\mathrm{E}_{11}$ バンド $(940-1350 \mathrm{~nm}$ ) のピーク強度が低下 し，CNTの酸化が確認された，注目すべきは， CNT-SDS に比べて CNT-BSA のピーク強度の低 下が小さい点である。比較のために, 図 1(a,b) に見られるピーク I-III の $\mathrm{pH}$ 依存性を図 1(c-e) にプロットした，CNT-BSA は反応中点が $\mathrm{pH} 3$ 付近に観察されたのに対し，CNT-SDS は pH 5 付近であり, BSA がCNT の酸化反応を効果的 に抑制していることが明らかになった。

CNT はバンドル化する過程で赤外光吸収又 ペクトルのブロード化が進む. ところが, CNT-BSA はエタノール添加によって凝集させ た後も， $\mathrm{E}_{11}$ バンドのスペクトルのピーク強度 を十分に保持することが確認された (Nakayama et al., 2018)。この結果からも, BSA は CNT 表 面に強固に吸着することが示唆される.

\section{CNT と蛋白質の酸化還元反応}

上記の実験によって, 蛋白質は CNT の表面 に吸着し, CNT と溶媒の間の酸化還元反応を 抑制する効果をもつことが明らかになった。し かしながら, CNT と吸着蛋白質の間の化学反 応については未知な点も多い. 研究代表者は以 前に, 下記の式 (2) に従って, 蛋白質のシステ イン（Cys）残基のスルフヒドリル基（RSH 基） がCNTにより酸化されることを示している (Hirano et al., 2017a; 2017b). 


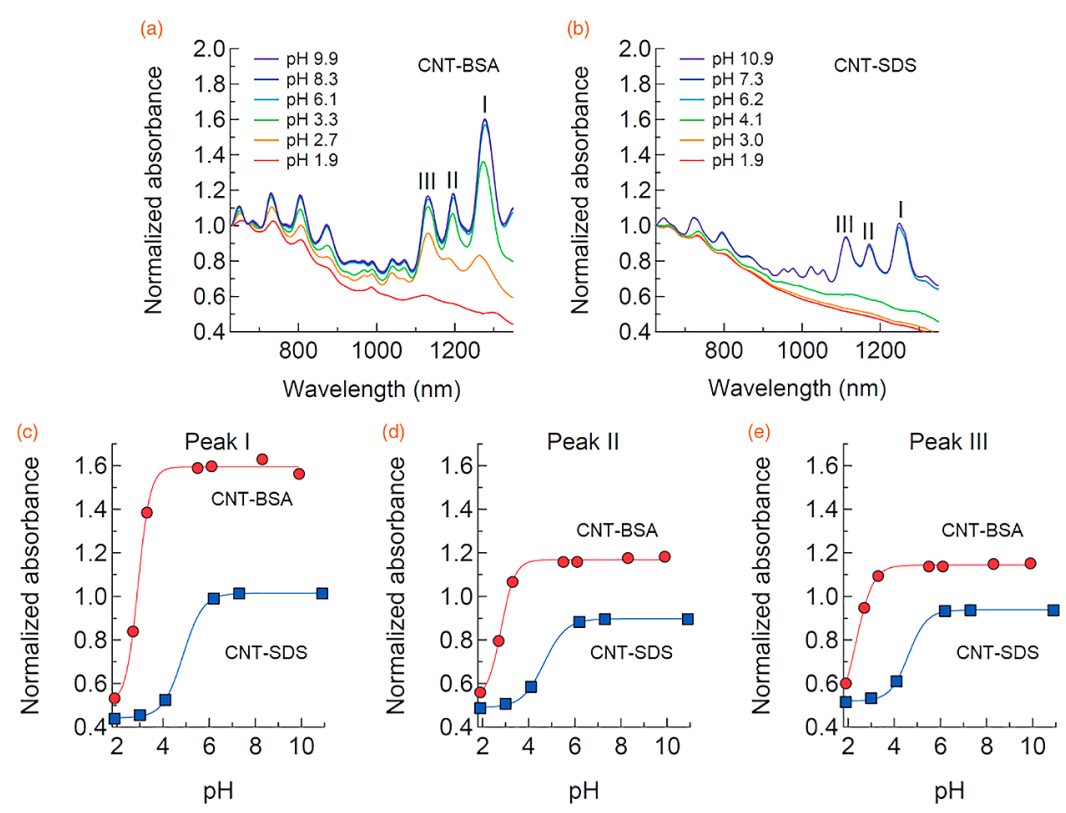

Fig. 1 pH dependence of the absorbance spectra of SWCNT-BSA (a) and SWCNT-SDS (b), which were normalized to the absorbance at $625 \mathrm{~nm}$. Normalized absorbances of SWCNT-BSA and SWCNT-SDS at peaks I (c), II (d), and III (e) as a function of pH. (Nakayama et al., 2018).

$$
2\left(\mathrm{~h}^{+}\right)_{\mathrm{CNT}}+2 \mathrm{RSH} \leftrightarrow 2\left(\mathrm{e}^{-} \mathrm{h}^{+}\right)_{\mathrm{CNT}}+\mathrm{RSSR}+2 \mathrm{H}^{+}
$$

一方で，SH 基の酸化は共存する遷移金属イ オンによって進行することも知られており, CNT の合成時に利用される遷移金属触媒由来 の残留遷移金属イオンが上記の反応に関与寸る ことが予測された、そこで, 金属イオンのキレー 卜剤である EDTAを利用し， CNT と SH 基の 酸化還元反応における遷移金属イオンの効果を 検証した（Hirano et al., 2019）. SH 基を持つ化 合物としては，アミノ酸のひとつである L-シ ステイン（Cys）を利用した。なお，使用した HiPco 法の CNT は, 触媒として鉄が利用され ているため, 鉄イオンが夾雑物として共存して いる.

図 2 にはCNT-SDS の分散溶液に, Cys や EDTA のほか, 人為的に鉄イオン $\left(\mathrm{Fe}^{3+}\right.$ と $\left.\mathrm{Fe}^{2+}\right)$ を添加した際の，1800 $\mathrm{s}$ 後の赤外光吸収スペク トルを示す．無添加（no additive）に比べ, Cys 添加時にはスペクトルの $\mathrm{E}_{11}$ バンドのピーク強 度の回復が観察された。これはCNT の還元 (同 時にCysの酸化）を示している。ところが,
Cys と EDTA を同時に添加した際のピーク強度 の回復は相対的に弱かった。 この結果は, 夾雑 する鉄イオンが反応に関与していることを示唆 している。一方, Cys と EDTA と共に $\mathrm{FeCl}_{3}$ を 加えた際には, ピーク強度はCysのみの場合 と同程度に回復した。しかしながら，容易に予 想できるように，酸化㓮である $\mathrm{FeCl}_{3}$ （+EDTA） のみではピーク強度は著しく低下し, 還元剤で ある $\mathrm{FeCl}_{2}$ （+EDTA）のみではピーク強度は高 い值を示した。

図 2(b)には，1250 nm 付近のピークの相対強 度 $\left(\theta_{\mathrm{CNT}}\right)$ の経時変化を示す $\left(\theta_{\mathrm{CNT}}\right.$ は全 $\mathrm{CNT}$ に対する還元型 CNT の割合に相当)。Cys のみ に比べ, Cys と EDTA を同時に添加した際には, $\theta_{\mathrm{CNT}}$ 值の回復速度が著しく低下することが明 らかとなった，特に注目すべきは，Cys と EDTA と共に $\mathrm{FeCl}_{3}$ を加えた際の結果である. $\theta_{\mathrm{CNT}}$ 值は観測できないほどの短時間で 0.1 付近 まで低下したのち， $1000 \mathrm{~s}$ ほどで 0.9 付近まで 急激に回復した。この結果は, 反応初期には $\mathrm{Fe}^{3+}$ が CNT を酸化させる反応が優先されるも のの, 一部の $\mathrm{Fe}^{3+}$ は $\mathrm{Cys}$ を酸化させ, $\mathrm{Fe}^{2+}$ に 変化し，それが CNT を還元させたことを示唆 

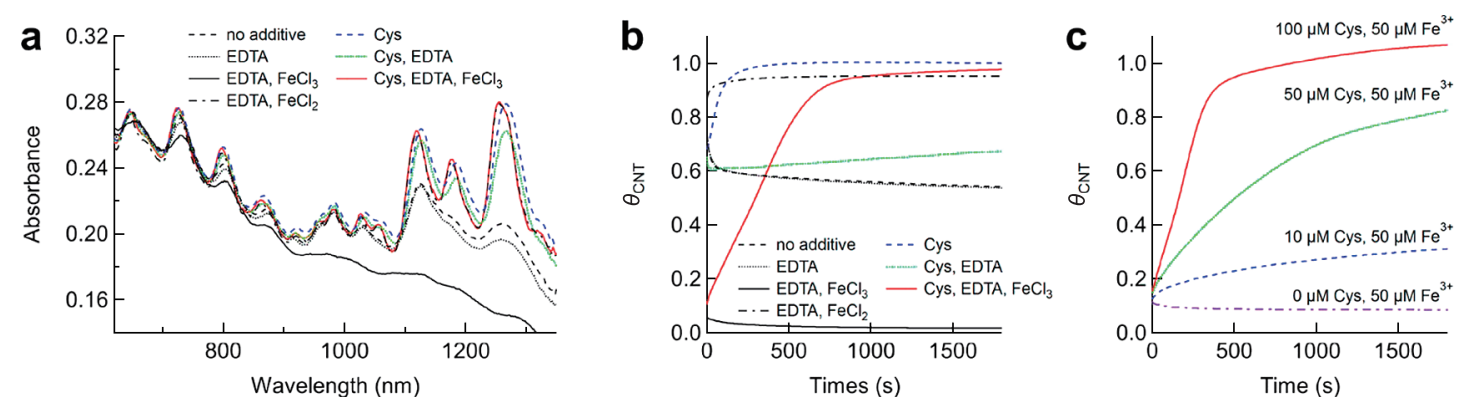

Fig. 2 Redox reaction of the CNTs with Cys. (a) Representative absorption spectra of the CNTs in the $\mathrm{S}_{11}$ and $\mathrm{S}_{22}$ regions under different conditions more than $1800 \mathrm{~s}$ after sample preparation. The concentrations of $\mathrm{Cys}_{\mathrm{F}} \mathrm{FeCl}_{3}$, $\mathrm{FeCl}_{2}$, and EDTA used in this experiment were $100 \mu \mathrm{M}, 50 \mu \mathrm{M}, 50 \mu \mathrm{M}$, and $10 \mu \mathrm{M}$, respectively. (b) Time courses of fractional concentrations of the reduced CNTs $\left(\theta_{\mathrm{CNT}}\right)$. The fractional concentration of the reduced CNTs $\left(\theta_{\mathrm{CNT}}\right)$ was defined as the equation $\theta_{\mathrm{CNT}}=[\mathrm{CNT}] /\left([\mathrm{CNT}]+\left[\mathrm{CNT}^{+}\right]\right)$. The concentrations of the additives were identical to those used in the experiment described in panel a. (c) Time courses of the value of $\theta_{\mathrm{CNT}}$ in the different concentrations of Cys along with $50 \mu \mathrm{M} \mathrm{FeCl}_{3}$. Reprinted with permission from (Hirano et al. (2019)). Copyright 2019 American Chemical Society.

a

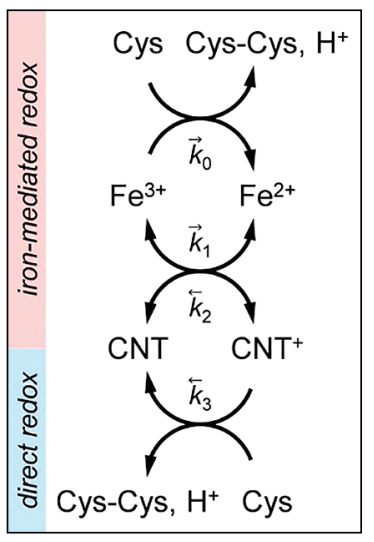

b
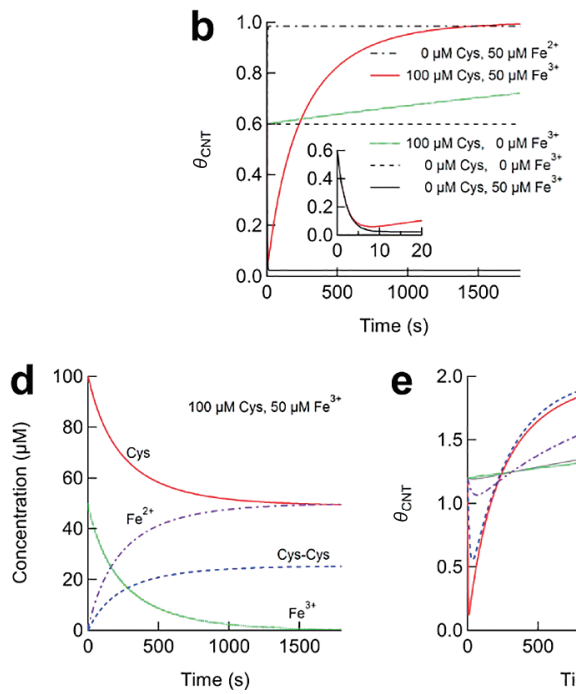

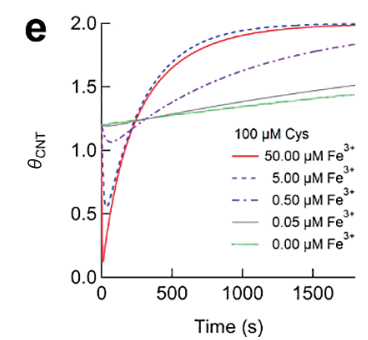

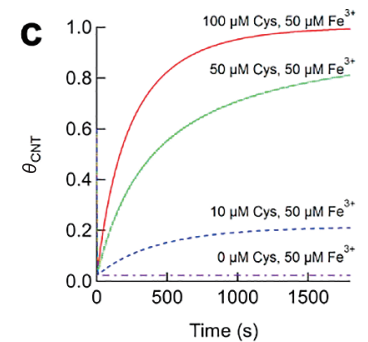

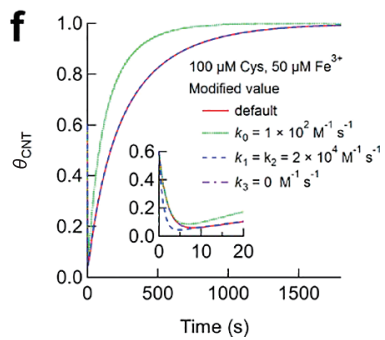

Fig. 3 Numerical simulation of the redox reaction of Cys with CNTs mediated by iron ions. The redox reaction of CNTs via the $\mathrm{O}_{2}, \mathrm{H}^{+} / \mathrm{H}_{2} \mathrm{O}$ couple was ignored in the simulations because the change in $\mathrm{pH}$ in the experiments was insignificant. (a) A suggested reaction scheme described with the reaction rate parameters $(k)$ of the elementary processes, where the values of $k$ are as follows: $k_{0}=5 \times 10 \mathrm{M}^{-1} \mathrm{~s}^{-1}, k_{1}=1 \times 10^{4} \mathrm{M}^{-1} \mathrm{~s}^{-1}, k_{2}=1 \times 10^{4} \mathrm{M}^{-1} \mathrm{~s}^{-1}$, and $k_{3}=2 \mathrm{M}^{-1} \mathrm{~s}^{-1}$. (b) Time courses of the values of $\theta_{\mathrm{CNT}}$ obtained from the numerical simulations under the different initial conditions described in the legend. The initial value of $\theta_{\mathrm{CNT}}$ was set to 0.6. (c) Time courses of the values of $\theta_{\mathrm{CNT}}$ under different initial conditions with the initial concentration of $50 \mu \mathrm{M} \mathrm{Fe}^{3+}$, as described in the legend. (d) Time courses of the concentration of each component obtained from the numerical simulation under the initial condition of $100 \mu \mathrm{M}$ Cys and $50 \mu \mathrm{M} \mathrm{Fe}^{3+}$. (e) Time courses of the values of $\theta_{\mathrm{CNT}}$ under different initial conditions with the initial concentration of $100 \mu \mathrm{M}$ Cys, as described in the legend. (f) Time courses of the values of $\theta_{\mathrm{CNT}}$ using the modified values of $k$ described in the legend. Note that the data using $k_{3}=0 \mathrm{M}^{-1} \mathrm{~s}^{-1}$ almost overlapped with the data using the default value throughout the time period. Reprinted with permission from (Hirano et al. (2019)). Copyright 2019 American Chemical Society. 
している。このような Cys が仲介した反応の 妥当性は図 2(c) に示した $\theta_{\mathrm{CNT}}$ 值の回復の Cys 濃度依存性からも支持される。

そこで，図3(a)に示す反応モデルを想定した。 なお, 反応速度については各素反応の観測によ り決定した。 その結果, 図 3(b,c)に示すように, 図 2(b,c) の実験結果を十分に再現する結果が 得られた。この結果をもとに, 反応物と生成物 の濃度の経時変化を抽出した結果, 当初の予想 通り, $\mathrm{Fe}^{3+}$ の濃度の低下と共に Cys の濃度が低 下し, 一方で $\mathrm{Fe}^{2+}$ と Cys の酸化物であるシス チン（Cys-Cys）の濃度が増加することが示さ れた (図 3(d))。 $\mathrm{Fe}^{3+}$ の触媒効果は, $\mathrm{Fe}^{3+}$ の濃 度依存性の結果からも明確であり（図 3(e)）, $\mathrm{Fe}^{3+}$ の共存によって CysによるCNT の還元が 著しく早まることが明らかになった。なお， $\mathrm{Fe}^{3+}$ 添加時に見られる反応初期の CNT の酸化 は $\mathrm{Fe}^{3+}$ による直接的な反応であるため, 反応 速度 $\left(k_{1}, k_{2}\right)$ に大きく依存する一方, その後の CNT の還元はCys を介した間接的な反応であ るため, 反応速度 $\left(k_{0}\right)$ に大きく依存する（図 $3(\mathrm{f})$ ).

以上のような CNT と Cys の酸化還元反応は Cys 残基を有するモデル蛋白質においても観測 された（Hirano et al., 2019）。このように, CNT と蛋白質の酸化還元反応は従来提案されていた 直接的な電子移動のほかに, 残留遷移金属イオ ンの触媒反応に起因するものが存在することが 明らかになった（図4）。そのほかに，CNTに よる蛋白質の酸化反応は, 夾雑する遷移金属に よって発生する活性酸素種（ROS）に起因する ことも提案されており (Ge C. et al., 2012), こ れらの反応が並行して蛋白質の酸化を進めるこ とが想定される。

\section{3. まとめ}

生体内に取り込まれた CNT は速やかに蛋白 質に覆われ，蛋白質コロナを形成するが，蛋白 質コロナ形成による CNT や蛋白質そのものの 物性変化については，これまで不明な点が多 かった，今回の成果によって, 蛋白質は CNT

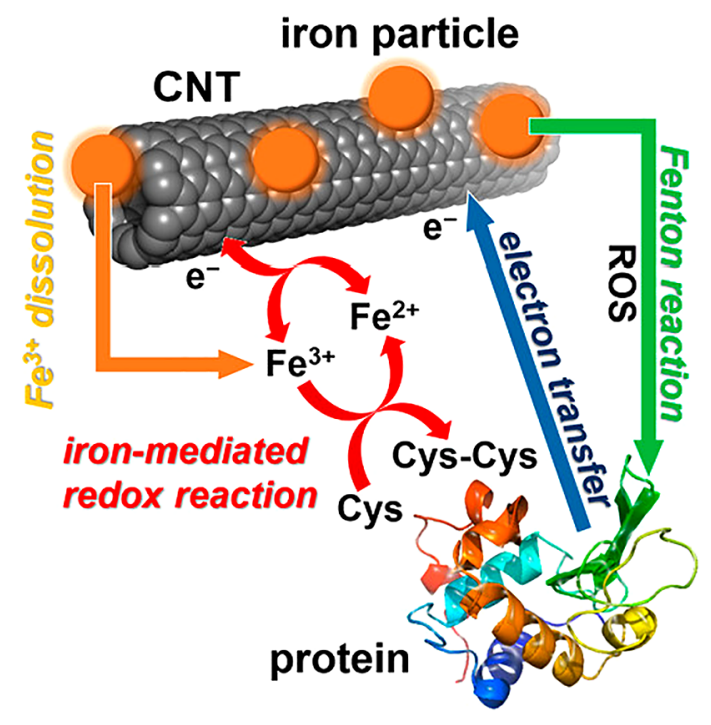

Fig. 4 A scheme of redox reactions of the CNTs with proteins. The reactions include iron-mediated redox reaction, direct electron transfer and ROSmediated redox reaction via the Fenton reaction. Reprinted with permission from (Hirano et al., 2019). Copyright 2019 American Chemical Society.

の表面全体に密に吸着し, CNTへの溶媒のア クセスを抑制する効果があること，さらには， 蛋白質の Cys 残基は共存する遷移金属イオン の媒介によって CNT の還元を効果的に進める と同時に Cys 残基の酸化が進むことが明らか になった。これらの知見は, ナノ材料の生体内 動態に関する基礎知見として大いに役立つと期 待される。

\section{参考文献}

Albanese A., Walkey C.D., Olsen J.B., Guo H., Emili A., Chan W.C.W., Secreted biomolecules alter the biological identity and cellular interactions of nanoparticles, ACS Nano, 8 (2014) 5515-5526. https://doi.org/10.1021/nn4061012

Ge C., Du J., Zhao L., Wang L., Liu, Y., Li D., Yang Y., Zhou R., Zhao Y., Chai Z., Chen C., Binding of blood proteins to carbon nanotubes reduces cytotoxicity, Proceedings of the National Academy of Sciences of the United States of America, 108 (2011) 16968-16973. https://doi.org/10.1073/pnas.1105270108

Ge C., Li Y., Yin J.-J., Liu Y., Wang L., Zhao Y., Chen C., The contributions of metal impurities and tube structure 
to the toxicity of carbon nanotube materials, NPG Asia Materials, 4 (2012) e32.

https://doi.org/10.1038/am.2012.60

Hirano A., Kameda T., Sakuraba S., Wada M., Tanaka T., Kataura H., Disulfide bond formation of thiols by using carbon nanotubes, Nanoscale, 9 (2017a) 5389-5393. https://doi.org/10.1039/c7nr01001j

Hirano A., Kameda T., Wada M., Tanaka T., Kataura H., Carbon nanotubes facilitate oxidation of cysteine residues of proteins, The Journal of Physical Chemistry Letters, 8 (2017b) 5216-5221.

https://doi.org/10.1021/acs.jpclett.7b02157

Hirano A., Wada M., Tanaka T., Kataura H., Oxidative stress

\section{論文発表}

1. Hirano A., Wada M., Tanaka T., Kataura H., Oxidative stress of carbon nanotubes on proteins is mediated by metals originating from the catalyst remains, ACS Nano, 13 (2019) 1805-1816. https://doi.org/10.1021/acsnano.8b07936

2. Nakayama T., Tanaka T., Shiraki K., Hase M., Hirano A., Suppression of single-wall carbon nanotube redox reaction by adsorbed proteins, of carbon nanotubes on proteins is mediated by metals originating from the catalyst remains, ACS Nano, 13 (2019) 1805-1816.

https://doi.org/10.1021/acsnano.8b07936

Nakayama T., Tanaka T., Shiraki K., Hase M., Hirano A., Suppression of single-wall carbon nanotube redox reaction by adsorbed proteins, Applied Physics Express, 11 (2018) 075101 (5pp). https://doi.org/10.7567/APEX.11.075101

Zheng M., Diner B.A., Solution redox chemistry of carbon nanotubes, Journal of the American Chemical Society, 126 (2004) 15490-15494.

https://doi.org/10.1021/ja0457967

Applied Physics Express, 11 (2018) 075101

(5pp). https://doi.org/10.7567/APEX.11.075101

\section{口頭・ポスター発表}

1. 平野篤, 和田百代, 田中丈士, 片浦弘道, “カーボンナノチューブによるタンパク質の 酸化反応における触媒由来金属の効果”, 第 55 回フラーレン・ナノチューブ・グラフェン 総合シンポジウム（Sendai, Sept. 11, 2018) 1-1. 